(2) Open Access Full Text Article

REVIEW

\title{
Immunological and genetic aspects of asthma and allergy
}

This article was published in the following Dove Press journal:

Journal of Asthma and Allergy

19 August 2010

Number of times this article has been viewed

\author{
Anne-Marie Madore \\ Catherine Laprise \\ Université du Québec à Chicoutimi, \\ Département des sciences \\ fondamentales, Saguenay, Canada
}

\begin{abstract}
Prevalence of allergy and allergic asthma are increasing worldwide. More than half of the US population has a positive skin prick test and approximately $10 \%$ are asthmatics. Many studies have been conducted to define immunological pathways underlying allergy and asthma development and to identify the main genetic determinants. In the effort to find missing pieces of the puzzle, new genomic approaches and more standardized ones, such as the candidate gene approach, have been used collectively. This article proposes an overview of the actual knowledge about immunological and genetic aspects of allergy and asthma. Special attention has been drawn to the challenges linked to genetic research in complex traits such as asthma and to the contribution of new genomic approaches.
\end{abstract}

Keywords: immune response, allergy, asthma, genetics, genomics

\section{Allergy}

Allergy, also called hypersensitivity, is a reaction that occurs when the immune system responds to a harmless antigen. ${ }^{1}$ According to results published by the National Health and Nutrition Examination Surveys in 2005, more than half of the US population $(54.3 \%)$ tests positive to one or more allergens (a common antigen that gives rise to an immediate hypersensitivity response) $)^{2}$ using skin prick tests between 1988 and 1994. ${ }^{3}$ This survey also underlines the evidence of the growing prevalence of allergy in industrialized countries.

Allergies have been studied according to the different categories of allergens (indoor, outdoor, food, drug, etc) and according to the different allergic diseases (allergic rhinitis, atopic dermatitis, allergic asthma, etc). Prevalence of allergy to different types of antigen and prevalence of different allergic diseases ranges from $4 \%$ to $6 \%$ for food allergy, ${ }^{4}$ to $10 \%$ for allergic asthma, ${ }^{5}$ and up to $49 \%$ reported in one study for allergic rhinitis. ${ }^{6}$

\section{Immunology of allergy}

Hypersensitivity reactions have been classified by Coombs and Gell into four different types, characterized by different immunological mechanisms. ${ }^{7}$ These types have been well described in a review by Averbeck et al. ${ }^{1}$ A brief description of each type is as follows. Type I hypersensitivity refers to immediate hypersensitivity responses against foreign proteins that are common (pollen, grass, animal danders, etc). It can be observed in allergic rhinitis and allergic asthma (see section "immunology of asthma" for more detail). ${ }^{1,8}$ This type of hypersensitivity is characterized by immunoglobulin (Ig) E production during the sensitization phase, which will bind to FceRI receptors on mast cells and basophils. Upon renewed contact, the allergen will bind cellular IgE. Crosslinking
Correspondence: Catherine Laprise 555 boulevard de l'Université, Chicoutimi, Québec, G7H 2BI, Canada Tel + I 4 I8 54550 I I (ext. 5659) Fax + I 4I8 6I5 I203

Email catherine.laprise@uqac.ca 
of FceRI receptors will lead to degranulation of mast cells and basophils (see Figure 1). Mediators released that way will lead to immediate and, sometimes, delayed immune responses..$^{9,10}$

Type II hypersensitivity is a humoral response mediated by IgG or IgM that are produced against surface antigens on body cells. An example of type II hypersensitivity is drug-induced cytopenia caused by penicillin, cephalosporin, or transfusion reactions. ${ }^{1,11}$ Immune response occurs within minutes after antigen contact. In drug allergic subjects, IgG or IgM will be formed in response to drugs or their metabolites which accumulate in membrane structures. This binding will allow

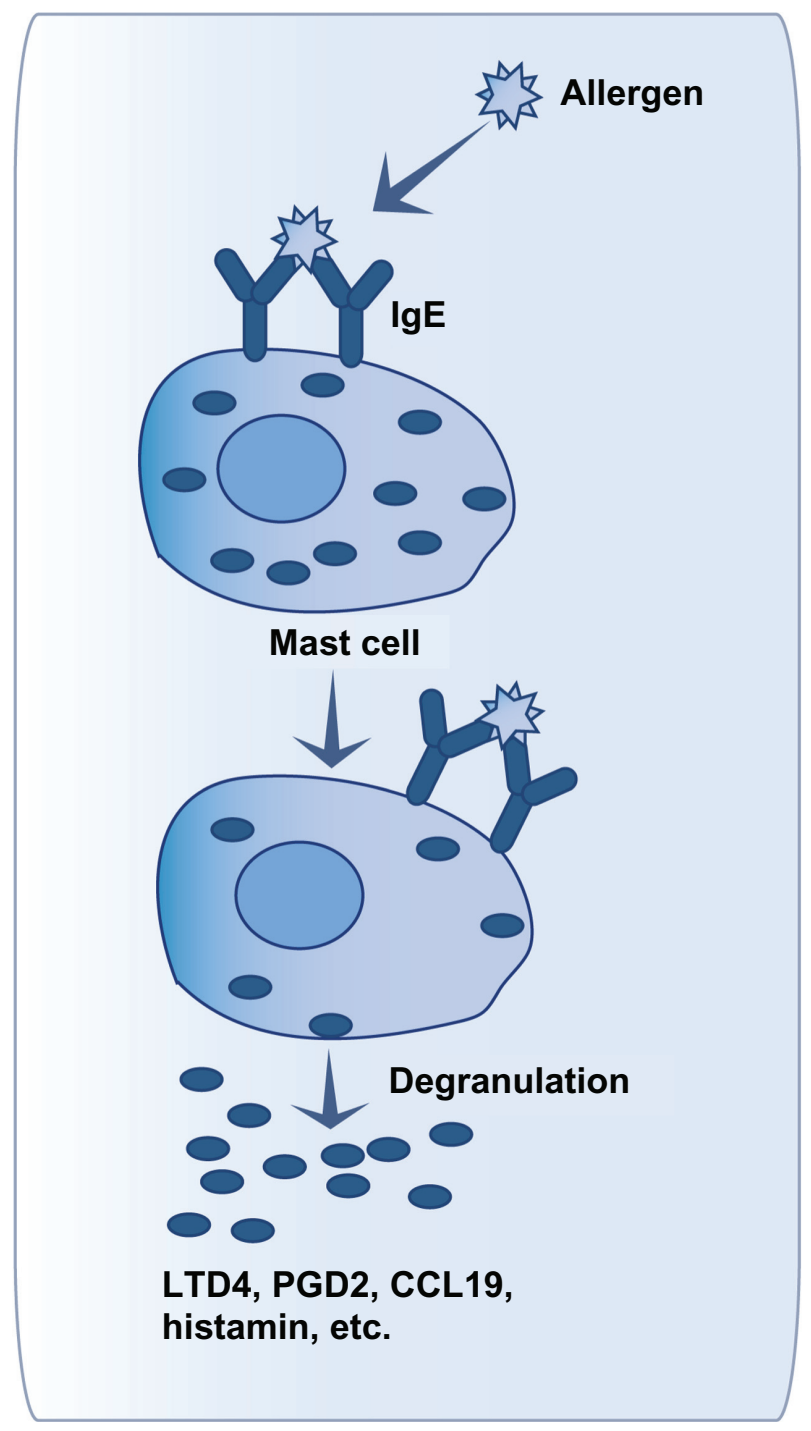

Figure I Mast cell activation after allergen contact.

Notes: When a first contact with allergen has already been made, immunoglobulin (Ig) E against this allergen have been produced by $B$ cells and have bound to FcER I $\beta$ receptors on mast cells. Another contact with the same allergen will allow its binding on cellular lgE on mast cells. This will produce a crosslinking of $F c \varepsilon R I \beta$, leading to activation and degranulation of mast cells within a few minutes. Modulators released by mast cells will promote inflammation by recruitment of new immune cells and activation of structural cells of the airways. the killing of the target cells by three different ways. ${ }^{1,11}$ The first one is the activation of the classic complement pathway, which will lead to cytolysis. The second one is the antibodydependant cell-mediated cytotoxicity, which will lead to lysis of target cells by natural killer cells. The last one is the recognition of Fc fragments of $\mathrm{IgG}$ and $\operatorname{IgM}$ by phagocytic cells, which will lead to opsonization of the target cells.

Type III hypersensitivity involves the formation of immune complexes that are not well cleared by innate immune cells as in malaria, rheumatoid arthritis, or farmer's lung. ${ }^{1,12}$ This response can occur within four to six hours. The accumulation of immune complexes (antigens bound to antibodies) in vessels and tissues can be caused by antigen excess for subjects with immunosuppression or insufficient antibody production. It can also be caused by repeated antigen exposure which will lead to excess IgG antibody production. The presence of those persistent immune complexes will give rise to an inflammatory response due to leukocytes' activation. ${ }^{1,12}$

Finally, type IV hypersensitivity is a delayed response principally mediated by T cells. ${ }^{1,13}$ The best known example of type IV hypersensitivity is contact allergy. The sensitization phase lasts 10-15 days and is asymptomatic. In contact allergy, a hapten, a low molecular weight molecule, will interact with skin cells or proteins. After this contact, Langerhans and dendritic cells will present antigen to naive $T$ cells to stimulate their differentiation into $\mathrm{CD}^{+}$and $\mathrm{CD} 8^{+} \mathrm{T}$ cells and to induce production of memory $\mathrm{T}$ cells. A renewed contact between the skin and the antigen will stimulate sensitized memory $T$ cells via antigen-presenting cells. Early arrival of $\mathrm{CD}^{+}$and $\mathrm{CD}^{+}$ $\mathrm{T}$ cells and activation of keratinocytes, will all contribute to promote inflammatory reaction via cytokine secretion. Finally, this reaction will be controlled by regulatory T cells. ${ }^{1,13}$

This classification of allergic reactions has been widely accepted but some revised nomenclature was proposed, such as that of Johansson et $\mathrm{al}^{14}$ who are part of the European Academy of Allergy and Clinical Immunology. This revised nomenclature, based on known immune mechanisms of allergic diseases and hypersensitivity, aimed to classify the hypersensitivity reactions according to the presence of allergy, IgE production, and atopy. This classification gives a more universal definition of hypersensitivity, regardless of the targeted tissue or organ.

\section{Genetics of allergy}

Twin studies have demonstrated the strong heritable component of allergic diseases and atopy, estimated at 33\%-76\%. ${ }^{15,16}$ Twin studies with monozygous mice revealed that, even with the same controlled environment, phenotypic variability can 
occur in allergic manifestations. These results demonstrated that environment explains about $30 \%$ of the phenotypic variability observed in allergy and that $70 \%$ is due to other factors, such as epigenetics. ${ }^{17,18}$

However, search of the genes involved in allergy have been mostly done when studying genetic factors of allergic diseases (Table 1). Indeed, as mentioned by Hong et al, ${ }^{19}$ it is often difficult to evaluate the implication of genes on the development of allergy, using this method. However, Renkonen et $\mathrm{al}^{20}$ have recently published a review of the genetics of allergic diseases and have found 39 genes associated with allergy. ${ }^{20}$ In an effort to classify these genes according to their principal pathway, they concluded that 25 of them are involved in the same interaction pathway with another 70 proteins. Among all of these proteins, 20 are linked to the "host-virus interactions". When looking to Gene Ontology categories, "response to stress" and "response to various stimuli" were also significantly enriched. ${ }^{20}$ Another interesting finding of this study is the proportion of protein kinases in their results (23\%). Indeed, those kinases may be involved in active allergen transport through intact epithelium. ${ }^{20}$

To give a general idea of the genes identified by genetic studies on allergic diseases, here are some of the general pathways represented: the T helper type 2 (Th2) immune response and $\operatorname{IgE}$ switching cytokines and receptors (IL4RA, IL5, IL13, FCER1A, etc), the chemokines and chemokine receptors ( $C X 3 C R 1, C C X C R 1, C C R 2$, etc), the human leukocyte antigen (HLA; $H L A-D P B 1, H L A-D Q B 1$, etc), and the lipoxygenase and cyclooxygenase pathways (CYSLTR1, $L T C 4 S$, etc). ${ }^{6,19-26}$ Table 1 shows the prevalence of allergy or some of the most studied allergic diseases and the number of genes already associated with each ones.

\section{Asthma}

One of the most studied allergic diseases is asthma. Asthmatic response is provoked by allergy in $75 \%-80 \%$ of all asthmatic cases. ${ }^{29}$ According to the Global Initiative for Asthma, ${ }^{30}$ asthma is defined as a chronic inflammatory disorder of the airways involving many cells and mediators. The principal associated symptoms are airway hyperresponsiveness and usually reversible airflow obstruction. These symptoms lead to recurrent episodes of wheezing, breathlessness, chest tightness, and coughing.

Clinical manifestations of asthma often appear during childhood. ${ }^{31}$ However, some individuals show a late onset, sometimes after the age of 40 years. ${ }^{32}$ According to articles published between 1987 and 1997, the prevalence of asthma varied between $0.5 \%$ and $6 \%$ depending on the regions of the world. ${ }^{33-37}$ Approximately 10 years later, it is estimated that
300 million people suffer from asthma in the world and that this number will reach 400 million people by $2025 .^{5}$ This represent a world prevalence of approximately $10 \%$ and a prevalence of $14.1 \%$ for Canada and of $10.9 \%$ for the United States. $^{5}$

\section{Physiopathology and immunology of asthma}

Asthma is a complex trait that is influenced by several genes as well as by the environment, thus it presents heterogeneous clinical manifestations always recognized as different subphenotypes. Researchers agree that asthma is not a single disease but rather an array of disorders that share common characteristics. ${ }^{29,38,39}$ These characteristics are inflammation, intermittent bronchial obstruction, bronchial hyperreactivity, mucus hypersecretion, and hypertrophy and hyperplasia of smooth muscle. ${ }^{8,38}$

As mentioned above, in $75 \%-80 \%$ of cases ${ }^{40,41}$ these phenotypes are caused by an allergic response, which triggers a Th2 immune response. ${ }^{29}$ It is a type I hypersensitivity reaction, that is an immediate exaggerated or harmful immune reaction. ${ }^{8,42}$ Interestingly, only $7 \%$ of allergic people develop asthma, ${ }^{43}$ which can lead us to believe that they present a unique phenotype that distinguishes them from other allergic, but nonasthmatic, individuals. The main immune cells involved in asthma are $\mathrm{CD} 4^{+} \mathrm{T}$ cells, mast cells, and eosinophils. ${ }^{44}$ The different steps of the inflammatory response in asthma, from contact with the allergen to remodeling, are illustrated in Figure 2 and explained later.

\section{Contact with the allergen}

When an allergen penetrates the airways, if not expulsed by the mucociliary barrier, it comes in contact with dendritic cells

Table I Prevalence and number of genes associated with allergy or most studied allergic diseases ${ }^{27-29}$

\begin{tabular}{|c|c|c|c|}
\hline $\begin{array}{l}\text { Allergy/allergic } \\
\text { disease }\end{array}$ & Prevalence & $\begin{array}{l}\text { Number of } \\
\text { associated } \\
\text { genes }\end{array}$ & References \\
\hline Allergy & $54 \%$ & 43 & $3,20,27$ \\
\hline Allergic asthma & $10 \%$ & More than 150 & $5,22,24$ \\
\hline Allergic rhinitis & $9 \%-42 \%$ & 21 & 6 \\
\hline $\begin{array}{l}\text { Atopic } \\
\text { dermatitis }\end{array}$ & $\begin{array}{l}16 \% \text { of children } \\
\text { in industrialized } \\
\text { countries }\end{array}$ & 46 & 21,23 \\
\hline $\begin{array}{l}\text { Drug allergy } \\
\text { (aspirin } \\
\text { intolerance) }\end{array}$ & $\begin{array}{l}1 \%-2 \% \text { of all } \\
\text { admissions and } \\
3 \%-5 \% \text { of } \\
\text { hospitalized patients }\end{array}$ & 24 & $25,26,28$ \\
\hline Food allergy & $\begin{array}{l}6 \% \text { of children and } \\
\text { up to } 4 \% \text { of adult }\end{array}$ & 9 & 4,19 \\
\hline
\end{tabular}


which will internalize and then digest the allergen. Some dendritic cells then migrate towards the lymph nodes to present the antigen to naive T cells (Figure 2A). ${ }^{45,46}$ This presentation happens through the major histocompatibility complex type II conjugated to the CD80 and CD86 costimulation molecules. ${ }^{47}$

The introduction of the antigen to naive $\mathrm{T}$ cells triggers the differentiation of $\mathrm{CD}^{+} \mathrm{T}$ cells into Th1 or Th2. This differentiation is modulated by the cytokines present during the introduction of the allergen, eg, interleukin (IL)-12 (Figure 2A). ${ }^{48}$ Evidence show, at least for mild to moderate asthma, that Th2 cells predominate. ${ }^{49}$ Thus, after the differentiation of naive $\mathrm{T}$ cells in Th2 cells, the latter produce cytokines, including IL-4 which induces the production of IgE by B lymphocytes (Figure 2A).

\section{Immediate response}

When an individual has already been in contact with an allergen, its presence and the presence of $\operatorname{IgE}$ can activate mast cells and stimulate their degranulation just minutes after the contact with the allergen., ${ }^{2,8}$ The activation happens when the allergen binds with more than one $\operatorname{IgE}$, which are linked to their high-affinity receptor (FceRI; Figure 2B). ${ }^{9,10}$ Mast cells are key cells in immediate response. In fact, mast cell granules contain proinflammatory molecules such as histamine, tryptase and other proteases, tumor necrosis factor (TNF), and heparin. ${ }^{2}$ New molecules are also produced and then released. These molecules are leukotrienes and prostaglandins, as well as cytokines, chemokines, and matrix metalloproteinases. ${ }^{2,50-53}$ The releasing of these mediators triggers the development of immediate response symptoms such as coughing, bronchial spasms, smooth muscle contraction, oedema, mucus secretion, and infiltration of immune cells. ${ }^{8,54}$ Mast cells, through these mediators, contribute to the recruitment and activation of immune cells in the lungs, such as eosinophils, T cells, macrophages, basophils, neutrophils, structure cells (fibroblasts, smooth muscle and epithelial cells), and other mast cells..$^{52,55,56}$

Basophils, with the presence of FceRI receptors on their surface and the expression of Th2 cytokines, histamine and granules, can also play a role in immediate response. However, their role in asthma is less documented than that of mast cells. ${ }^{57}$

\section{Delayed response}

Delayed, or late response, is not present in all asthmatics. It is mainly modulated by immune cells recruited by mast cells (Figure 2C). ${ }^{8,29}$ Among these cells, eosinophils are the main cells implicated in the development of this response. ${ }^{58}$ Eosinophils produce Th2 cytokines, ${ }^{59-61}$ leukotrienes, ${ }^{62-64}$ and proteins that cause damage to airway cells, such as major basic protein, eosinophil cationic protein, eosinophil-derived neurotoxin, and eosinophil peroxidase..$^{65,66}$

\section{Chronic inflammation in airways}

Chronic response in asthma is characterized by a persisting inflammation and the presence of structure alterations in the airways (Figure 2D). ${ }^{67}$

Several immune cells play a role in this response. Mast cells participate in the chronic response through mediators that have an effect on bronchoconstriction and on airway remodeling causing contraction, hypertrophia and hyperplasia of smooth muscles as well as fibrogenesis. ${ }^{50-53,68,69}$ Dendritic cells that remain in the airways after coming in contact with the allergen repeatedly present the antigen to $\mathrm{CD}^{+}{ }^{+} \mathrm{T}_{\text {cells. }}{ }^{70}$ These cells, as well as the activated $\mathrm{T}$ cells, produce proinflammatory cytokines, maintain the chronicity of the inflammation and the eosinophilia. ${ }^{8,45,46,71}$ Eosinophils are indirectly involved in bronchial remodeling regarding collagen deposit, fibrogenesis, angiogenesis, and hyperplasia of smooth muscles in the peripheral airways via mediators secretion and other cells activation. ${ }^{58,72-74}$

Structural cells also play an important role in maintaining the chronic response. The amount of mucous epithelial cells increases in asthmatics, thus participating in the bronchial obstruction, mainly in peripheral airways. ${ }^{75,76}$ Furthermore, epithelial cells, smooth muscle cells, and fibroblasts produce and/or store cytokines, chemokines, and other proinflammatory mediators. ${ }^{77-80}$ In asthmatics, fibroblasts also produce more collagen and other macromolecules for the extracellular matrix, and present an increased differentiation in myofibroblasts. $^{81,82}$

\section{Phenotypic variability in asthma}

To complete this overview of the asthmatic allergic response, the phenotypic heterogeneity has to be taken into consideration. Indeed, apart from allergic asthma, which is the most common form, other types of asthma have been described. ${ }^{8,38,83}$ One type is called nonallergic asthma, which develops independently from an allergic component. ${ }^{32}$ More research still has to be conducted to better define biological pathways specific to this form of asthma. ${ }^{84,85}$ However, as with allergic asthma, the scientific community recognizes that IgE could be implicated in an inflammatory cascade, as well as $\mathrm{CD}^{+}$and $\mathrm{CD} 8^{+} \mathrm{T}$ cells, eosinophils, and mast cells. ${ }^{86-91}$

A second type of asthma is characterized by sensitivity to aspirin. It is estimated that approximately $10 \%-20 \%$ of adult asthmatics suffer from this particular type. ${ }^{92}$ Aspirin 


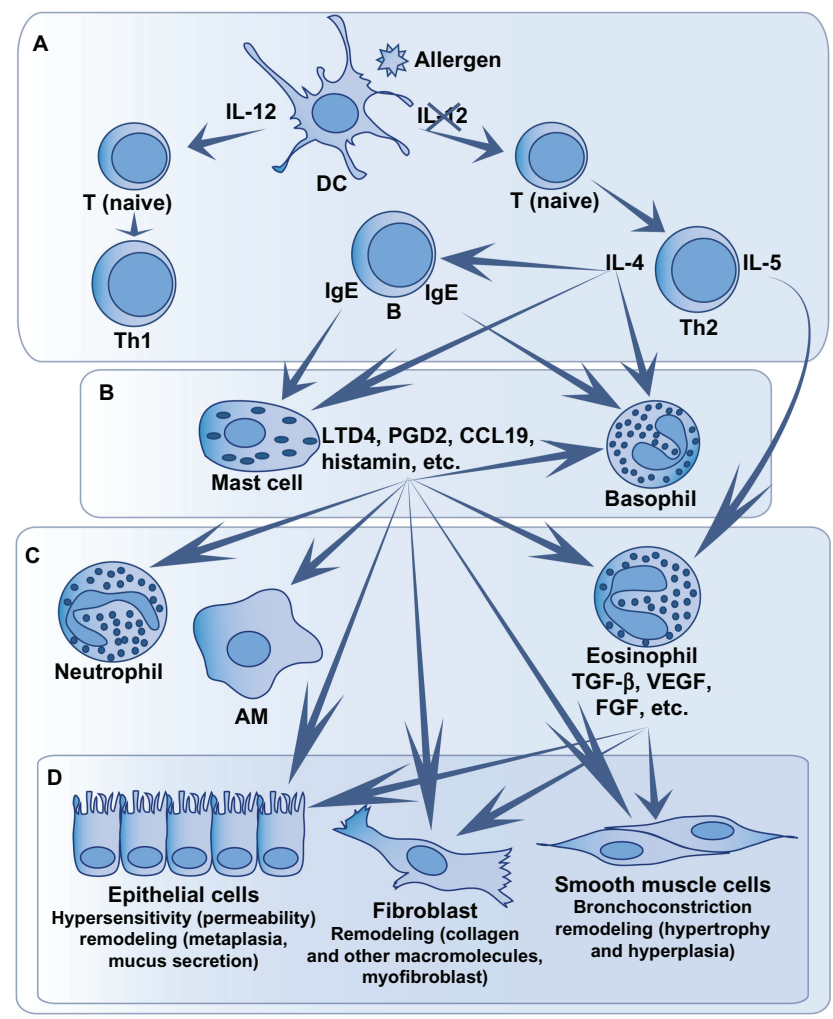

Figure 2 Immune response in asthma.

Notes: The immune response in asthma begins with $(\mathbf{A})$ the contact between antigen-presenting cells (mostly dendritic cells [DC]) and the allergen. These cells stimulate naive $T$ cell differentiation into $T$ helper type I (ThI) or Th2 type. Interleukin (IL)- 4 secretion by Th2 cell leads to the immunoglobulin (Ig) $\mathrm{E}$ production by $\mathrm{B}$ cells. IgE will bind to high-affinity receptors on mast cells and basophils and will allow immediate response to occur when another contact with the allergen will take place (B). After this new contact, mediators released by mast cells will induce recruitment and activation of other immune cell types as eosinophils, neutrophils, basophils, alveolar macrophages (AM), and structural cells (epithelial cells, smooth muscle cells, and fibroblasts). These cell types promote the delayed response that is not present in all asthmatic subjects (C). These cells not only promote the inflammatory response but also provoke hyperreactivity, bronchoconstriction, and remodeling. This will lead to asthma chronicity (D).

sensitization is thought to be non- $\operatorname{IgE}$ mediated so could be considered as a nonallergic subphenotype of asthma. ${ }^{92} \mathrm{~A}$ dysfunction of the eicosanoid metabolism is responsible for this type of asthma. ${ }^{92,93} \mathrm{~A}$ great number of individuals affected with this type of asthma will also resist a treatment with corticosteroids. ${ }^{38}$

Asthmatics who do not respond to glucocorticoid treatments represent up to $10 \%$ of all patients affected with asthma. ${ }^{94}$ This type of asthma can be induced by a diminution of the number of glucocorticoid receptors, by a misrecognition of the ligand by the receptors, by a decreased capacity of the receptors to link with DNA, or by an increase in the expression of certain proinflammatory transcription factors such as nuclear factor (NF)- $\kappa \mathrm{B} .{ }^{94}$

Occupational asthma is exacerbated or induced by irritants or particles present in the workplace of the affected..$^{95}$ It is estimated that $9 \%-15 \%$ of all cases of asthma in adults are linked to the workplace and that up to $25 \%$ of new cases of adult asthma fall in the occupational asthma category. ${ }^{96,97}$

Finally, exercise-induced asthma affects $7 \%-15 \%$ of the general population and 3\%-14\% of athletes. ${ }^{98}$ A study indicates that up to $39 \%$ of college athletes show one of the main symptoms of asthma, that is bronchoconstriction. ${ }^{99}$ The two major hypotheses that could explain the induction of asthma after an effort are related to the augmentation of ventilation in the lungs. ${ }^{100,101}$ These two hypotheses are the osmotic hypothesis (dehydration by evaporation caused by the increase in ventilation) and the thermal hypothesis (airway cooling during exercise and rewarming after exercise). ${ }^{101-103}$ According to Anderson and Daviskas, ${ }^{101}$ maybe a mix of these two hypotheses could better explain the phenotype rather than each one separately.

Asthma can also be classified according to inflammatory patterns. The three principal types are eosinophilic asthma, neutrophilic asthma, and paucigranulocytic asthma. ${ }^{39}$ Paucigranulocytic asthma is defined as an asthma response without eosinophils or neutrophils. ${ }^{29}$

Another way to classify asthma is according to the severity of the phenotype. This classification is used in the clinical treatment, but is also used in research in order to document the molecular and cellular biology variation related to the severity of the disease. Intermittent, mild, moderate, or severe asthma are part of this classification. ${ }^{104}$ The definition criteria of these types of asthma include frequency of day and night symptoms, exacerbation, and maximum expiratory flow in one second (Table 2). ${ }^{30}$

Changes in principal cells involved in the inflammatory response have been observed according to the severity of asthma. For example, inflammation is located in the main airways in individuals with mild asthma, whereas it is also present in peripheral airways and alveoli in individuals with severe asthma or during exacerbation. ${ }^{105}$ It is also interesting to note that a recruitment of $\mathrm{Th} 1$ and $\mathrm{CD} 8^{+} \mathrm{T}$ cells (cytotoxic $\mathrm{T}$ cells) has also been observed in the case of severe and chronic asthma and during exacerbation. ${ }^{106-108}$ Thus, other cell types involved in the Th1 response or in immune response regulation, such as alveolar macrophages (they inactivate dendritic cells and they can be activated or inhibited through different pathways), ${ }^{109-111}$ could play a role in the inflammatory response observed in asthma. ${ }^{112,113}$

\section{Asthma genetics}

Several studies demonstrated a strong familial structure in the prevalence of asthma. ${ }^{11-119}$ Studies conducted on twins on asthma and its subphenotypes (IgE, bronchial hyperreactivity, 
etc) supported the idea of a genetic component in the development of asthma. ${ }^{116}$ Segregation analyses subsequently demonstrated that asthma does not follow a Mendelian transmission model. In fact, aggregation and segregation analyses have demonstrated that asthma is polygenic (several genes implicated), shows genetic heterogeneity (different combinations of genes appear in the families that are studied), and pleiotropy (some genes are implicated in the development of more than one phenotype). Moreover, environment plays also a role in the development of the phenotype. ${ }^{116,120}$ According to this, asthma is considered as a complex trait.

Many challenges appear in genetic research on asthma, such as (1) finding all the genes associated with asthma and with treatment responses (build a list of asthma genes), (2) defining the mechanisms that trigger the phenotypic heterogeneity observed in asthma (assess the contribution of each gene in the different asthma phenotypes), (3) understanding the biology of the mutated genes in the etiology of the disease (functional role of the associated genes), (4) understanding how the gene-gene and gene-environment interactions work (develop biological and mathematical analysis tools), ${ }^{121}$ and (5) defining the impact of the epigenetic modulations on the development of asthma. ${ }^{120}$

The ultimate goal beyond these challenges is to define principal pathways involved in asthma and also pathways specifically involved in asthma subphenotypes to find targets for new treatments. ${ }^{122}$ According to the great phenotypic variability observed in asthma, a more precise description of pathways involved in asthma subphenotypes would increase our chance to develop more efficient treatments for people who do not respond to actual therapy. An ideal therapy should be specific enough to be taken orally without affecting the immune response in the whole body. ${ }^{122}$ Actually, potential targets identified (for example, mediator antagonists and inhibitors of cytokines, p38 MAP kinase inhibitors, and antiinflammatory cytokines) are maybe too specific to be very effective. ${ }^{122}$ In the search for genes and pathways involved in asthma, association studies between genes or the entire genome and drug response phenotypes could also lead to pharmacogenetic therapies. ${ }^{123}$ Indeed, characterizing the genetic profile of an asthmatic patient through genetic tests targeting specific genes of interest could help to select the appropriate treatment or to predict asthma development ${ }^{123,124}$ and allow improved prevention programs.

\section{Genes associated with asthma}

Several reviews have described the knowledge acquired on the genetics of asthma. ${ }^{22,24,121,125}$ Figure 3 classified the main genes associated with asthma according to their biological function into three principal categories: inflammation, remodeling, and other pathways. Most of the associated genes could be classified into the inflammation $(32 / 61$; $52 \%)$ or remodeling categories $(12 / 61 ; 20 \%)$. Indeed, this classification not only underlines the great proportion of associated genes in the inflammatory response, but also underlines the need to better define the biological function for some of the other genes (other pathways; 17/61, $28 \%$ ) to better understand their implication in asthma. The complete list of genes for all categories seen in Figure 3 is available in Table 3 with ontology keywords.

Table 4 presents the same 61 genes classified according to the approach used to target them. As shown in this table, the main approach that has been used in the research of genetic determinants of asthma is the candidate gene approach. At the end of 2005, more than 100 genes had already been associated to asthma and another 54 associations have been performed in 2006 and 2007. ${ }^{22,24}$ Candidate gene association studies are based on the hypothesis of an association between the variants of a gene and asthma or one of its associated phenotypes. These phenotypes usually include respiratory capacity (wheezing, bronchial hyperreactivity, and pulmonary function measurements), immunological measures (total or specific blood $\operatorname{IgE}$, allergy) or clinical criteria (atopic dermatitis, eczema, and rhinoconjunctivitis). ${ }^{121}$ This approach implies a literature review on genes involved in the development of the trait, or closely related to biological pathways linked with physiopathology of the trait. The choice of candidate genes can be based on several types of information: (1) gene functions, (2) documented associations with the trait in other populations or with closely related phenotypes, (3) difference of expression of the gene for the trait or a closely related phenotype, (4) at least one of these criteria documented for an animal model, or (5) association of another gene in the same biological pathway with the trait or with closely related phenotypes. ${ }^{22,127}$ Consequently, this approach is biased according to the literature already published for the specific trait and the possibility of discovering new potentially interesting genes could be limited. ${ }^{22,127}$ This limitation may be even more important considering that the underlying biology of the development of most complex traits remains to be defined. ${ }^{127}$

In order to go past this candidate gene selection bias, several approaches have been described. One of these is to select the candidate genes according to their known functions and to crosscheck the results with data obtained from genome-wide linkage, association, or expression studies. ${ }^{127}$ These genomic 
approaches allow targeting of new genes without having to state a hypothesis regarding a specific gene or locus and, therefore, permit to increase the knowledge on the pathology of the trait. ${ }^{22,130}$

Before going further on the contributions of these techniques on the genetics of asthma, here is a brief description of each of them. Linkage analysis and genome-wide association studies (GWAS) are two techniques used to identify chromosomal loci associated in a studied trait. In both cases, analyses are based on two principles: equal transmission of alleles and increase in recombination for increased distances between two markers. ${ }^{131}$ To identify those loci, the linkage analysis uses families to compare microsatellite markers transmission with phenotype transmission. Similarities between these two transmissions are translated into a statistical measure, the lod score. The lod score is greater when markers of a locus are more transmitted to sick children in studied families, and it is possible to hypothesize that genes near this locus are involved in the development of this disease. ${ }^{132}$ For GWAS, familial or case-control cohorts can be used. ${ }^{133}$ Contrary to linkage analysis, different genetic variant types can be used for GWAS as coding single nucleotide polymorphisms (SNPs), tagging SNPs, or copy number variants. Figure 4 presents a brief description of the methodology used for this technique. Linkage analysis has been very efficient to target genes responsible of monogenic trait development but, ${ }^{132,134}$ in complex traits, one disadvantage of linkage analysis is its impossibility to detect locus with modest effect on phenotype compared with GWAS. ${ }^{22,135}$ GWAS also has the advantage of targeting more specific chromosomal regions $(\leq 500 \mathrm{bp}$ ) because of the great number of genetic variants (more than 500,000 variants) represented on a microarray (for examples, see: http://www.illumina.com/).22 Moreover, new developments on genetics as HapMap international project, the development of new technologies as microarrays, and the possibility to bring together many samples owned by different researchers opened the way to GWAS. ${ }^{121,136}$

Genome-wide expression studies are another genomic approach that allow the identification of new genes and pathways involved in a target disease. Figure 4 presents the main technical steps to perform genome-wide expression studies using Affymetrix technology as example. These studies, as GWAS, used microarrays. The expression of more than 25,000 genes or transcripts can be measured in the same microarray (www.affymetrix.com). These are used to compare gene expression profiles of affected and nonaffected subjects, of treated and nontreated subjects, of measures for the same subjects at pretreatment and posttreatment, etc. Some advantages of genome-wide expression studies are accessibility of the microarray technology and analysis tools for researchers and clinicians, no sequencing step and possibility to study thousands of genes simultaneously. ${ }^{137}$

About the contribution of these genome-wide techniques, the use of linkage studies has allowed targeting of genes involved in biological pathways that had not been studied in asthma before (Table 4). Several chromosomal regions have been associated with asthma using this method, but only a few have been replicated in several studies and populations (5q31-33, 6p21, 12q13-q24). ${ }^{22,138}$ GWAS and genome-wide expression studies are now also being used in order to target new genes or validate observations about already associated genes in asthma. Until now, more than 62 genome-wide expression studies have been performed on asthma or one of its subphenotypes (as found in PubMed using "asthma and microarray" and "asthma and gene chip" keywords and according to Rolph et $\mathrm{al}^{139}$ ). Although most results obtained from expression microarrays are exploratory and must be validated through functional or association studies, a few genes have been targeted by these analyses (Table 4). ${ }^{128}$ As for GWAS, only a few studies have been performed on asthma so far. The first was conducted during the summer of 2007

Table 2 The definition criteria used to classify asthma according to severity

\begin{tabular}{|c|c|c|c|c|}
\hline Severity & Intermittent & Mild persistent & Moderate persistent & Severe persistent \\
\hline Symptom frequency & Less than once a week & $\begin{array}{l}\text { More than once per week } \\
\text { but less than once per day }\end{array}$ & Daily & Daily \\
\hline Nighttime symptoms & $\begin{array}{l}\text { Less than or equal to } \\
\text { twice per month }\end{array}$ & More than twice per month & More than once per week & Frequent \\
\hline Exacerbations & Brief & $\begin{array}{l}\text { Could affect activities } \\
\text { and sleep }\end{array}$ & Could affect activities and sleep & Frequent \\
\hline $\begin{array}{l}\text { FEV, percent of } \\
\text { predicted value }\end{array}$ & $\geq 80 \%$ & $\geq 80 \%$ & $60 \%-80 \%$ & $<60 \%$ \\
\hline Variability of FEV, & $<20 \%$ & $20 \%-30 \%$ & $>30 \%$ & $>30 \%$ \\
\hline
\end{tabular}

Note: Adapted from the Global Strategy for Asthma Management and Prevention, Global Initiative for Asthma (GINA). ${ }^{30}$

Abbreviation: $\mathrm{FEV}_{1}$, forced expiratory volume in the first second. 


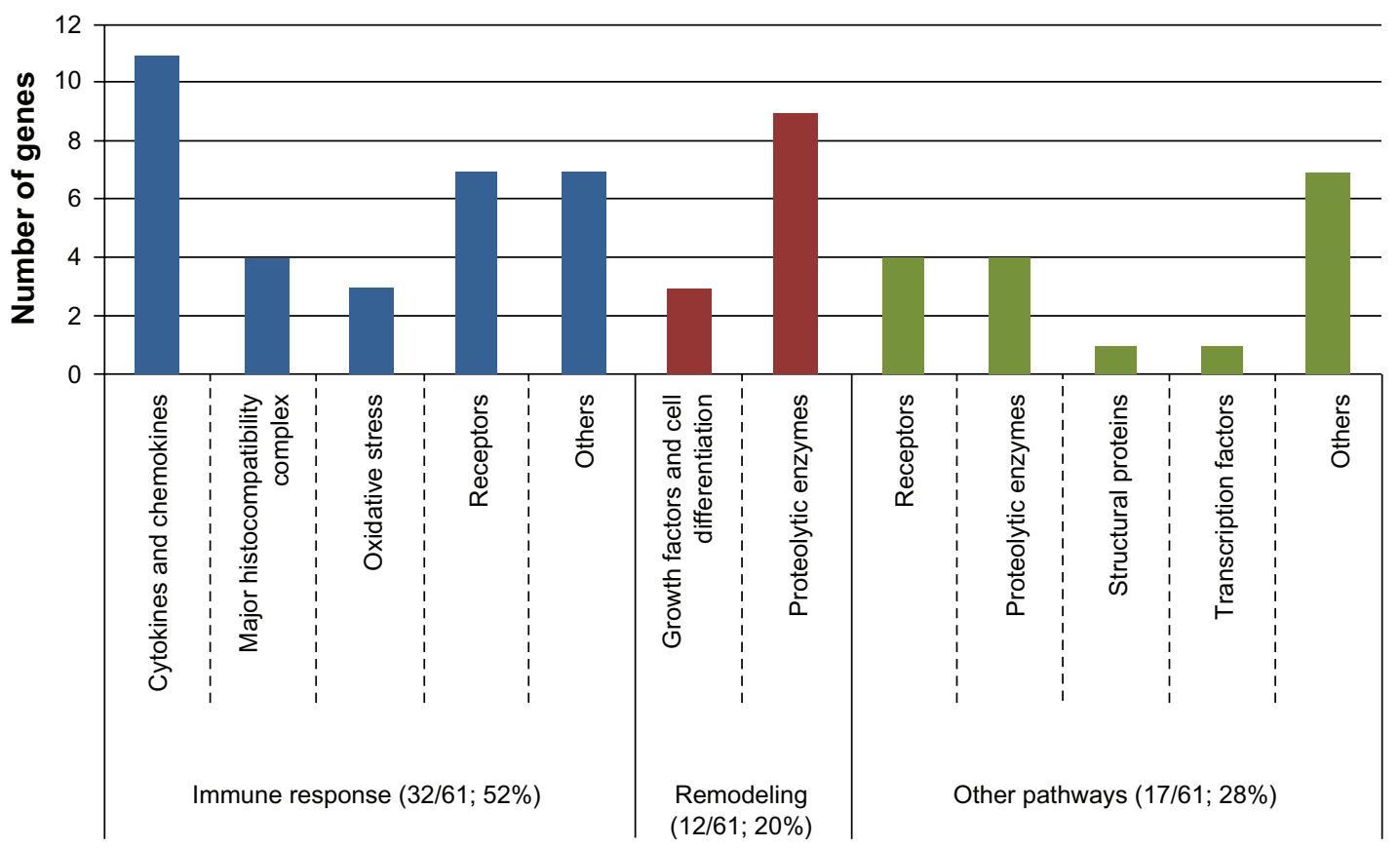

Figure 3 Classification of the 61 main associated genes with asthma into biological functions.

Notes: This figure illustrates the two levels of classification of the $6 \mathrm{I}$ main associated genes with asthma. The first level of classification is made according to their known principal functions. From these known functions, a possible implication in the immune response or the remodeling response has been deduced. It is interesting to note that more than half $(52 \%)$ of the main associated genes are in direct link with the immune response and that $20 \%$ may be involved in the remodeling process observed in asthma lung tissues. For the 17 genes classified in the "other pathways" category, their principal known function should help us orientate future research to better document their role in asthma. The complete list of genes for all categories seen in Figure 3 is available in Table 3 with ontology keywords.

and allowed targeting of a chromosomal region that regulates the expression of the ORMDL3, GSDMB, and ZPBP2 genes. ${ }^{140,141}$ However, GWAS approach is becoming more popular and many studies are underway in the field of asthma research. For example, to increase statistical power of the studies, researchers on asthma or other lung diseases group their samples together. Indeed, two major consortia have been made and will soon publish GWAS results. They are called GABRIEL Project (http://www.gabriel-fp6.org/) and EVE Asthma Genetics Consortium (http://arrafunding.uchicago.edu/investigators/ober_c.shtml). GABRIEL includes independent asthma genetics studies of European ancestry and EVE includes independent ones from the United States. The scientific community, including these two consortia and others, actually work to plane a meta-global GWAS analysis. The great number of data researchers obtain from these studies will allow them to target new genes and pathways involved in asthma development or its subphenotypes. These may become new therapeutic candidates or may be part of a predictive genetic profile. ${ }^{124}$

\section{Replication discrepancies}

However, no matter what kind of approach is used, researchers are confronted with the same question: why is there an absence of validation in several cases? These nonreplications can be linked to the statistical power of the samples used, or to other phenotypic, genetic, environmental, or epigenetic concerns. $^{121}$

To increase the chance to find polymorphisms associated with asthma and also replicate anterior results, statistical power of the sample is important. Genetic association studies are more powerful than genomic studies regarding number of subjects to number of genetic variants ratio. Indeed, with the great number of genetic variants or genes tested, the multiple testing problems are much more important in GWAS and genome-wide expression studies. ${ }^{142,143}$ It is known that for a GWAS, a sample of approximately 15,000 individuals would be necessary to obtain a statistical power of approximately $90 \%$ with a type I error of $5 \% .{ }^{144}$ This objective can be reached by grouping together all asthma genetic research studies. For expression studies, analyses showed that at least three to five samples per phenotypic group could be sufficient to find a difference of expression, depending on the objective of the study (ie, to look at greater or smaller differences of expression). ${ }^{145}$

Another cause of replication discrepancies is the great phenotypic heterogeneity observed in asthma, as described in the section "Phenotypic variability in 
Table 3 Classification of the $6 \mathrm{I}$ main genes associated with asthma according to their respective ontology keywords

\begin{tabular}{|c|c|c|c|c|}
\hline Categories & Gene symbol & Gene ID & Molecular function $^{a}$ & Biological process $^{a}$ \\
\hline \multicolumn{5}{|c|}{ Inflammation } \\
\hline \multicolumn{5}{|c|}{ Cytokines and chemokines } \\
\hline & CCLII & 6356 & Chemokine & \multirow{2}{*}{$\begin{array}{l}\text { Cytokine and } \\
\text { chemokine-mediated } \\
\text { signaling pathway }\end{array}$} \\
\hline & CCL5 & 6352 & Chemokine & \\
\hline & CTLA4 & 1493 & Other cytokine & T-cell mediated immunity \\
\hline & ILI8 & 3606 & Interleukin & \multirow{6}{*}{$\begin{array}{l}\text { Cytokine and } \\
\text { chemokine-mediated } \\
\text { signaling pathway }\end{array}$} \\
\hline & IL4 & 3565 & Interleukin & \\
\hline & ILI3 & 3596 & Interleukin & \\
\hline & ILIO & 3586 & Interleukin & \\
\hline & IL4R & 3566 & Interleukin receptor & \\
\hline & LTA & 4049 & $\begin{array}{l}\text { Tumor necrosis factor } \\
\text { family member }\end{array}$ & \\
\hline & $S C G B I A I(C C I 6)$ & 7356 & Other cytokine & Other immune and defense \\
\hline & $T N F$ & 7124 & $\begin{array}{l}\text { Tumor necrosis factor } \\
\text { family member }\end{array}$ & $\begin{array}{l}\text { Cytokine and chemokine-mediated } \\
\text { signaling pathway }\end{array}$ \\
\hline \multicolumn{5}{|c|}{ Major histocompatibility complex } \\
\hline & HLA-DRBI & 3123 & $\begin{array}{l}\text { Major histocompatibility } \\
\text { complex antigen }\end{array}$ & \multirow[t]{4}{*}{ MHCll-mediated immunity } \\
\hline & $H L A-D Q B I$ & 3119 & $\begin{array}{l}\text { Major histocompatibility } \\
\text { complex antigen }\end{array}$ & \\
\hline & HLA-DPBI & 3115 & $\begin{array}{l}\text { Major histocompatibility } \\
\text { complex antigen }\end{array}$ & \\
\hline & HLA-G & 3135 & $\begin{array}{l}\text { Major histocompatibility } \\
\text { complex antigen }\end{array}$ & \\
\hline \multicolumn{5}{|c|}{ Oxidative stress } \\
\hline & GSTM I & 2944 & Other transferase & \multirow[t]{3}{*}{ Detoxification } \\
\hline & GSTPI & 2950 & Other transferase & \\
\hline & GSTTI & 2952 & $\begin{array}{l}\text { Other transferase; } \\
\text { epimerase/racemase }\end{array}$ & \\
\hline \multicolumn{5}{|l|}{ Receptors } \\
\hline & $C D / 4$ & 929 & Other receptor & Immunity and defense \\
\hline & CX3CRI & 1524 & G-protein coupled receptor & $\begin{array}{l}\text { Cytokine and chemokine-mediated } \\
\text { signaling pathway }\end{array}$ \\
\hline & CYSLTRI & 10800 & G-protein coupled receptor & Immunity and defense \\
\hline & HAVCRI & 26762 & $\begin{array}{l}\text { Immunoglobulin receptor family } \\
\text { member; defense/immunity protein }\end{array}$ & $\begin{array}{l}\text { Other receptor-mediated } \\
\text { signaling pathway }\end{array}$ \\
\hline & IRAK3 & 11213 & $\begin{array}{l}\text { Serine/threonine protein kinase } \\
\text { receptor; protein kinase }\end{array}$ & $\begin{array}{l}\text { Protein phosphorylation; other } \\
\text { immune and defense }\end{array}$ \\
\hline & MS4A2 (FCERIB) & 2206 & $\begin{array}{l}\text { Immunoglobulin receptor family } \\
\text { member; defense/immunity protein }\end{array}$ & $\begin{array}{l}\text { B-cell mediated and antibody-mediated } \\
\text { immunity; other immune and defense }\end{array}$ \\
\hline & TRG@ ${ }^{\mathrm{b}}$ & & $\mathrm{T}$ cell receptor gamma locus & \\
\hline \multicolumn{5}{|c|}{ Other pathways } \\
\hline & $A L O X I 5$ & 246 & Oxygenase & $\begin{array}{l}\text { Other lipid, fatty acid and steroid } \\
\text { metabolism; immunity and defense }\end{array}$ \\
\hline & CMAI & 1215 & Serine protease & $\begin{array}{l}\text { Proteolysis; granulocyte-mediated } \\
\text { immunity }\end{array}$ \\
\hline & $H S P D I^{\mathrm{b}}$ & 3329 & Chaperonin & Protein folding \\
\hline & LTC4S & 4056 & & $\begin{array}{l}\text { Other lipid, fatty acid and steroid } \\
\text { metabolism; T-cell mediated immunity; }\end{array}$ \\
\hline & & & Other transferase & $\begin{array}{l}\text { B-cell mediated and antibody- } 6+ \\
\text { mediated immunity }\end{array}$ \\
\hline & $P R N P^{b}$ & 5621 & Molecular function unclassified & Biological process unclassified \\
\hline & STAT6 & 6778 & $\begin{array}{l}\text { Other transcription factor; } \\
\text { nucleic acid binding }\end{array}$ & $\begin{array}{l}\text { mRNA transcription regulation; } \\
\text { JAK-STAT cascade }\end{array}$ \\
\hline & $T B \times 2 I$ & 30009 & $\begin{array}{l}\text { Other transcription factor; } \\
\text { nucleic acid binding }\end{array}$ & $\begin{array}{l}\text { mRNA transcription regulation; } T \text {-cell } \\
\text { mediated immunity }\end{array}$ \\
\hline
\end{tabular}


Table 3 (Continued)

\begin{tabular}{|c|c|c|c|c|}
\hline Categories & Gene symbol & Gene ID & Molecular function ${ }^{a}$ & Biological process $^{a}$ \\
\hline \multicolumn{5}{|l|}{ Remodeling } \\
\hline \multicolumn{5}{|c|}{ Growth factors and cell differentiation } \\
\hline & AREG & 374 & Growth factor & Ligand-mediated signaling \\
\hline & GSDMB & 55876 & Molecular function unclassified & Developmental processes \\
\hline & TGFBI & 7040 & Growth factor & $\begin{array}{l}\text { Other receptor-mediated signaling } \\
\text { pathway }\end{array}$ \\
\hline \multicolumn{5}{|c|}{ Proteolytic enzymes } \\
\hline & $A C E$ & 1636 & Metalloprotease & Proteolysis \\
\hline & ADAM33 & 80332 & Metalloprotease & \\
\hline & $\mathrm{CHISLI}$ & 1116 & Glycosidase & Other polysaccharide metabolism \\
\hline & $\operatorname{chi3l3}(y m I)^{\mathrm{b}}$ & $\begin{array}{l}12655 \\
\text { (Mus musculus) }\end{array}$ & Molecular function unclassified & Biological process unclassified \\
\hline & NOSI & 4842 & $\begin{array}{l}\text { Synthase; oxidoreductase; } \\
\text { calmodulin-related protein }\end{array}$ & Electron transport \\
\hline & PLAU & 5328 & Serine protease & Proteolysis \\
\hline & SERPINEI (PAII) & 5054 & Serine protease inhibitor & \\
\hline & SERPINHI & 871 & Serine protease inhibitor & \\
\hline & SERPINB4 & 6318 & Serine protease inhibitor & \\
\hline \multicolumn{5}{|c|}{ Other pathways } \\
\hline \multicolumn{5}{|c|}{ Proteolytic enzymes } \\
\hline & ARGI & 383 & Other hydrolase & Amino acid catabolism \\
\hline & ARG2 & 384 & Other hydrolase & \\
\hline & NAT2 & 10 & Acetyltransferase & Other metabolism \\
\hline & PDE4D & 5144 & Phosphodiesterase & Metabolism of cyclic nucleotides \\
\hline \multicolumn{5}{|l|}{ Receptors } \\
\hline & $A D R B 2$ & 154 & G-protein coupled receptor & G-protein mediated signaling \\
\hline & NPSRI (GPRA) & 387129 & G-protein coupled receptor & \\
\hline & OPN3 & 23596 & G-protein coupled receptor & \\
\hline & $T B X A 2 R$ & 6915 & G-protein coupled receptor & G-protein mediated signaling \\
\hline \multicolumn{5}{|c|}{ Structural proteins } \\
\hline & FLG & 2312 & Other cytoskeletal proteins & Protein complex assembly \\
\hline \multicolumn{5}{|c|}{ Transcription factors } \\
\hline & VDR & 7421 & $\begin{array}{l}\text { Nuclear hormone receptor; } \\
\text { transcription factor }\end{array}$ & mRNA transcription regulation \\
\hline \multicolumn{5}{|l|}{ Others } \\
\hline & COL29A $I^{\mathrm{b}}$ & 256076 & Molecular function unclassified & Cell adhesion \\
\hline & CYFIP2 & 26999 & Other G-protein modulator & Signal transduction \\
\hline & DPPIO & 57628 & Select regulatory molecule & Protein targeting and localization \\
\hline & ORMDL3 & 94103 & Other miscellaneous function protein & Miscellaneous \\
\hline & PHFII & 51131 & Double-stranded DNA binding protein & General mRNA transcription activities \\
\hline & POSTN & 10631 & Other cell adhesion molecule & Cell adhesion \\
\hline & SPINK5 & I I005 & Select regulatory molecule & Homeostasis \\
\hline
\end{tabular}

Notes: a Ontology keywords from the Panther Classification System (http://www.pantherdb.org/). ${ }^{b}$ Genes not recognized by the Panther Classification System. Those have been classified according to description available in Entrez Gene by NCBI (http://www.ncbi.nlm.nih.gov/gene). See also Madore et al. ${ }^{126}$

asthma". This phenotypic heterogeneity can reflect genotypic heterogeneity, thus implying that the severity and onset of asthma could be influenced by the asthmatics' genetic imprint. ${ }^{146,147}$ Thus, a precise characterization of the subjects remains essential. This precise phenotypic description of the sample helps to better select similar independent samples to replicate genetic association results and so helps to reduce the impact of differences in recruitment criteria and in population stratification between samples. ${ }^{146}$ According to the fact that asthma is rather a collection of several diseases than a unique trait, the key of replication success may lie in association studies with asthma subphenotypes. The review article written by Wenzel ${ }^{39}$ presents several ways to categorize asthma subphenotypes that can be used for association and expression studies.

Gene-environment interactions are another source of variability since the environment can modulate the effect of 
Table 4 List of the $6 \mathrm{I}$ main associated genes in genetic and genomic studies on asthma and classified according to their identification method

\begin{tabular}{|c|c|c|c|c|}
\hline \multicolumn{5}{|c|}{ Genes identification methods } \\
\hline Candidate genes ${ }^{a}$ & & Linkage analysis ${ }^{\mathrm{b}}$ & GWAS & $\begin{array}{l}\text { Genomic expression } \\
\text { studyc }^{c}\end{array}$ \\
\hline$\underline{A D R B 2}$ & $H L A-D Q B I$ & $\operatorname{ADAM} 33^{\circ}$ & CHI3LI & $\underline{A L O X 15}$ \\
\hline$\overline{A C E}$ & HLA-DRBI & COL29AI & $\underline{\underline{G S D M B}}$ & AREG \\
\hline SCGBIAI $(C C I 6)$ & IL4 & CYFIP2 & $\overline{O R M D L 3}$ & $A R G I$ \\
\hline CCL5 & $\underline{I L 4 R}$ & CYSLTRI & PDE4D & ARGII \\
\hline CCLII & ILIO & $\overline{D P P I 0}$ & TCR $\gamma$ ou & CX3CRI \\
\hline$C D / 4$ & $1 L I 3$ & HLA-G & TARP (BC072396) & HSPDI \\
\hline CMAI & $1 L / 8$ & IRAKM & & $\overline{\text { PLAU }}$ \\
\hline CTLA4 & LTA & $N P S R I(G P R A)^{a}$ & & POSTN \\
\hline MS4A2 (FCERIB) & LTC4S & OPN3 & & PRNP \\
\hline FLG & NAT2 & PHFII & & $\overline{S E R P I N E I}(P A I-I)$ \\
\hline GSTMI & NOSI & VDR & & SERPINB4 \\
\hline GSTPI & SPINK5 & & & SERPINHI \\
\hline GSTTI & STAT6 & & & $\overline{Y m l}(\mathrm{Chi3/3})$ \\
\hline HAVCRI & $\underline{\underline{T B X 21}}$ & & & \\
\hline \multirow[t]{3}{*}{ HLA-DPBI } & $\overline{T B X A 2 R}$ & & & \\
\hline & TGFB I & & & \\
\hline & $T N F$ & & & \\
\hline
\end{tabular}

Abbreviation: GWAS, genome-wide association study.

Notes: associated genes listed are those that have been replicated in almost five different studies according to Vercelli. ${ }^{121}$ Underlined genes are those that have been associated in more than 30 different studies. ${ }^{121}$ bAssociated genes are those targeted by linkage analysis according to Ober and Hoffjan ${ }^{22}$ and Moffatt. ${ }^{125}$ cPrincipal genes identified using genomic expression studies in asthma according to Izuhara and Saito. ${ }^{128}$ Genes in bold are those identified by Laprise et al ${ }^{129}$ and were positively associated with asthma. Genes in bold and underlined are those identified by Madore et al ${ }^{126}$ and that were validated by semi-quantitative real-time polymerase chain reaction (PCR). Double-underlined genes are newly five (or more) times associated genes in the 2009-2010 periods (keywords used in PubMed: gene association study).

a gene on the resulting phenotype. ${ }^{148}$ Studies showed that gene-environment interactions had a greater effect on the phenotype than the environment and genes separately. ${ }^{149}$ For example, some studies have demonstrated that a high exposure to endotoxin seems to switch the susceptibility effect of the CD14/159C allele to a protective effect compared with the CD14/-159T allele. ${ }^{150-152}$ Another example of gene-environment interaction is the interaction between polymorphisms in the regulating regions of a gene and the cell differentiation cycle, leading to differences on the expression of a specific allele. ${ }^{153}$

A part of the etiology of asthma could be explained by epigenetic changes. Epigenetics is the study of changes that are heritable and that modulate gene expression without directly altering gene sequence. ${ }^{120}$ Those changes can be done through DNA methylation or posttranslational modification of histones: eg, acetylation, methylation, phosphorylation, and ubiquitylation. ${ }^{154,155}$ Studies have demonstrated that epigenetic changes are heritable for almost two subsequent generations (eg, methylation of a coat-color gene in mice). ${ }^{156}$ Many studies in asthma underline the possible role of epigenetics in its development mostly for early onset asthma (for a review, see Miller and $\mathrm{Ho}^{120}$ ). For example, exposition to environmental tobacco smoke during prenatal development or during the first years of life could influence the development of asthma and may be transmitted across two generations. ${ }^{157-159}$

Gene-gene interactions are another source of variability. In complex traits, a single mutation often has a minor impact, but the combination of several mutations should increase the influences on a phenotype. In asthma, a synergy between a mutation in the IL4 (rs2243250), the IL13 (rs1800925), the IL4 R (rs1805010) and in the signal transducer and activator of transcription 6 (STAT6) (rs324011) genes was documented and increases by 10.8 times the risk of having a high level of $\operatorname{IgE}$ and by 16.8 times the risk of developing asthma. ${ }^{160}$

The solution to these replication problems might partly lie in new genomic methods. In fact, new developments in the field of genetic and genomic research (for example, microarrays for GWAS and genome-wide expression studies), as well as knowledge acquired on the genome and its polymorphisms (as the HapMap project) allow the implementation of new analysis tools. Indeed, although there is still no consensus regarding the analysis methods that should be employed, new tools have been developed to overcome these problems. For example, many new software packages are developed or optimized regularly in Bioconductor, an open source software for the analysis 


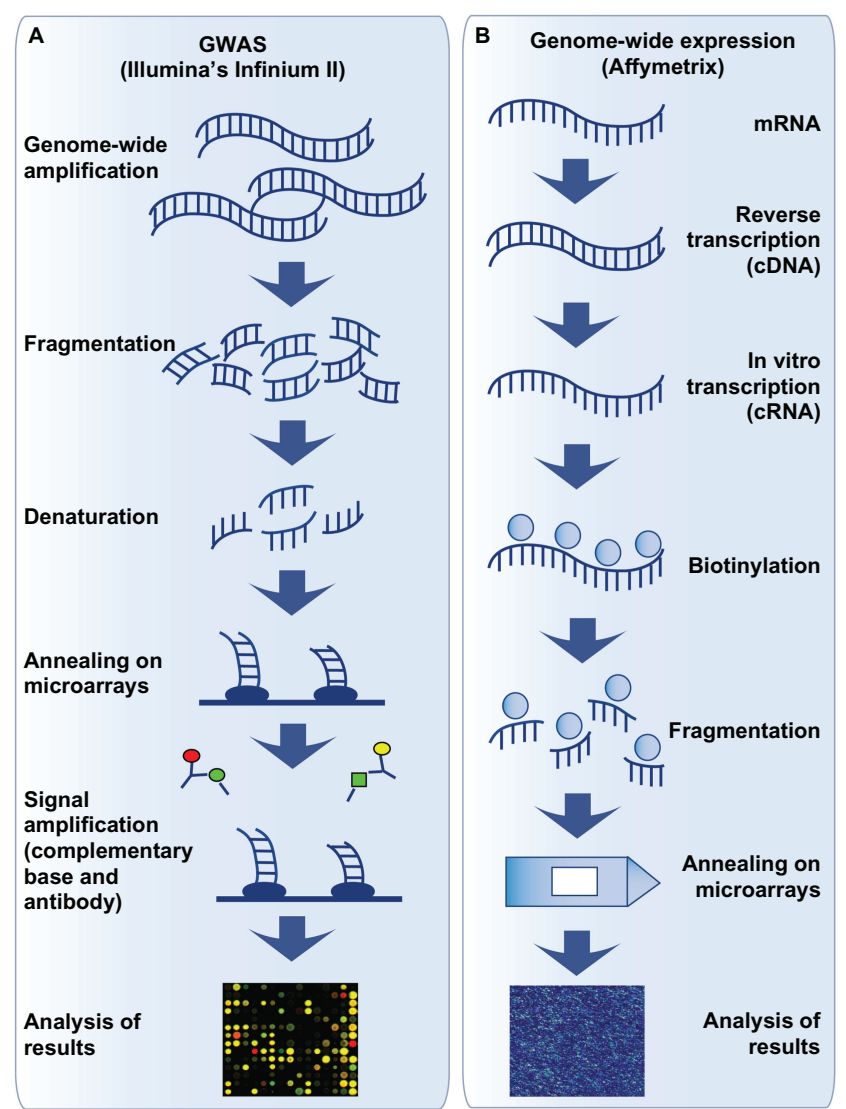

Figure 4 Illustration of the methodological steps for genome-wide association studies and genome-wide expression studies.

Notes: Part A of this figure illustrates methodological steps of genome-wide association studies (GWAS) done using Illumina technology. Briefly, the first step is the amplification of the complete genome. Second, amplified DNA is fragmented using digestion enzymes. Denaturized fragments are then hybridized to short oligonucleotide sequences on microarrays. Finally, amplification with a fluorescent complementary base pair will allow reading and analyzing the results (Illumina http:// www.illumina.com/pages.ilmn?ID=40). Part B of the figure illustrates methodological steps of genome-wide expression study performed using Affymetrix technology. The first step is the reverse transcription of mRNA into cDNA, followed by transcription of cDNA into cRNA. Afterward, cRNA is biotinylated, fragmented, and annealed with primers synthesized on the microarray. The signal intensity is proportional to the number of copies present in the sample.

and comprehension of genomic data, to better analyze and characterize data obtained from genome-wide studies (www.bioconductor.org). New genome-wide analysis tools are promising avenues to find new biological pathways, gene families or chromosomal loci involved in asthma and complex diseases, but candidate gene approach will remain a useful and powerful tool to refine our search for associated genes and to help better define the pathways involved in asthma development.

\section{Acknowledgment}

Catherine Laprise is the chair holder of the Canada Research Chair for genetic determinants in asthma (www.chairs. gc.ca) and is responsible for the inflammation and remodeling strategic group of the Respiratory Health Network
(RHN) of the Fonds de la recherche en santé du Quebec (FRSQ).

\section{Disclosure}

The authors report no conflicts of interest in this work.

\section{References}

1. Averbeck M, Gebhardt C, Emmrich F, Treudler R, Simon JC. Immunologic principles of allergic disease. J Dtsch Dermatol Ges. 2007;5(11): 1015-1028.

2. Platts-Mills TAE. Immediate hypersensitivity (Type I). In: Male D, Brostoff J, Roth DB, Roitt I, editors. Immunology. 7th ed. Philadelphia, PA: Elsevier; 2006:423-447.

3. Arbes SJ Jr, Gergen PJ, Elliott L, Zeldin DC. Prevalences of positive skin test responses to 10 common allergens in the US population: results from the third National Health and Nutrition Examination Survey. J Allergy Clin Immunol. 2005;116(2):377-383.

4. Lack G. New developments in food allergy: old questions remain. J Allergy Clin Immunol. 2004;114(1):127-130.

5. Masoli M, Fabian D, Holt S, Beasley R. Global burden of asthma. Developed for the Global Initiative for Asthma. Medical Research Institute of New Zealand, Wellington, New Zealand and University of Southampton, Southampton, United Kingdom; 2004.

6. Settipane RA, Charnock DR. Epidemiology of rhinitis: allergic and nonallergic. Clin Allergy Immunol. 2007;19:23-34.

7. Gell PGH, Coombs RRA. The classification of allergic reactions underlying disease. In: Coombs RRA, Gell PGH, editors. Clinical Aspects of Immunology. London, UK: Blackwell Science; 1963.

8. Verstraelen S, Bloemen K, Nelissen I, Witters H, Schoeters G, Van Den Heuvel R. Cell types involved in allergic asthma and their use in in vitro models to assess respiratory sensitization. Toxicol In Vitro. 2008;22(6):1419-1431.

9. Gilfillan AM, Tkaczyk C. Integrated signalling pathways for mast-cell activation. Nat Rev Immunol. 2006;6(3):218-230.

10. Metzger $\mathrm{H}$. The receptor with high affinity for IgE. Immunol Rev. 1992;125:37-48.

11. Male D. Hypersensitivity (Type II). In: Male D, Brostoff J, Roth DB, Roitt I, editors. Immunology. 7th ed. Philadelphia, PA: Elsevier; 2006: 449-460.

12. Hay F, Westwood OMR. Hypersensitivity (Type III). In: Male D, Brostoff J, Roth DB, Roitt I, editors. Immunology. 7th ed. Philadelphia: Elsevier; 2006:461-476.

13. Britton W. Type IV hypersensitivity. In: Male D, Brostoff J, Roth DB, Roitt I, editors. Immunology. 7th ed. Philadelphia, PA: Elsevier; 2006: 477-491.

14. Johansson SG, Hourihane JO, Bousquet J, et al. A revised nomenclature for allergy. An EAACI position statement from the EAACI nomenclature task force. Allergy. 2001;56(9):813-824.

15. Hopp RJ, Bewtra AK, Watt GD, Nair NM, Townley RG. Genetic analysis of allergic disease in twins. J Allergy Clin Immunol. 1984; 73(2):265-270.

16. Lichtenstein P, Svartengren M. Genes, environments, and sex: factors of importance in atopic diseases in 7-9-year-old Swedish twins. Allergy. 1997;52(11):1079-1086.

17. Isidoro-Garcia M, Davila-Gonzalez I, Pascual de Pedro M, Sanz-Lozano C, Lorente-Toledano F. Interactions between genes and the environment. Epigenetics in allergy. Allergol Immunopathol (Madr). 2007;35(6):254-258.

18. Gartner K. A third component causing random variability beside environment and genotype. A reason for the limited success of a 30 year long effort to standardize laboratory animals? Lab Anim. 1990; 24(1):71-77.

19. Hong X, Tsai HJ, Wang X. Genetics of food allergy. Curr Opin Pediatr. 2009;21(6):770-776.

20. Renkonen J, Mattila P, Parviainen V, Joenvaara S, Toppila-Salmi S, Renkonen R. A network analysis of the single nucleotide polymorphisms in acute allergic diseases. Allergy. 2010;65(1):40-47.

21. Barnes KC. An update on the genetics of atopic dermatitis: scratching the surface in 2009. J Allergy Clin Immunol. 2010;125(1):16-29, e1-e11; quiz 30-31. 
22. Ober C, Hoffjan S. Asthma genetics 2006: the long and winding road to gene discovery. Genes Immun. 2006;7(2):95-100.

23. Williams H, Robertson C, StewartA, etal. Worldwide variations in the prevalence of symptoms of atopic eczema in the International Study of Asthma and Allergies in Childhood. JAllergy Clin Immunol. 1999;103(1 Pt 1):125-138.

24. Zhang J, Pare PD, Sandford AJ. Recent advances in asthma genetics. Respir Res. 2008;9:4.

25. Palikhe NS, Kim SH, Park HS. What do we know about the genetics of aspirin intolerance? J Clin Pharm Ther. 2008;33(5):465-472.

26. Gueant JL, Gueant-Rodriguez RM, Gastin IA, et al. Pharmacogenetic determinants of immediate and delayed reactions of drug hypersensitivity. Curr Pharm Des. 2008;14(27):2770-2777.

27. Castro-Giner F, Bustamante M, Ramon Gonzalez J, et al. A poolingbased genome-wide analysis identifies new potential candidate genes for atopy in the European Community Respiratory Health Survey (ECRHS). BMC Med Genet. 2009;10:128.

28. Gomes ER, Demoly P. Epidemiology of hypersensitivity drug reactions Curr Opin Allergy Clin Immunol. 2005;5(4):309-316.

29. Holgate ST. Pathogenesis of asthma. Clin Exp Allergy. 2008;38(6): 872-897.

30. Global Initiative for Asthma. Global strategy for asthma management and prevention. 2008.

31. Global Initiative for Asthma. Global strategy for asthma management and prevention. 2006.

32. Humbert M. Does "intrinsic" asthma exist? Rev Mal Respir. 2000; 17(1 Pt 2):245-254.

33. Kerkhof M, De GraafA, Droste JHJ. Prevalentie van astmatische klachten in drie regio's in Nederland. Tijdschr Soc Gezondheidsz. 1994;72:181-185.

34. Platts-Mills TA, Carter MC. Asthma and indoor exposure to allergens N Engl J Med. 1997;336(19):1382-1384.

35. Rijcken B, Kerkhof M, de Graaf A. Europees Luchtweg Onderzoek Nederland (ELON). Groningen: Rijksuniversiteit Groningen; 1996.

36. Turkeltaub PC, Gergen PJ. Prevalence of upper and lower respiratory conditions in the US population by social and environmental factors: data from the second National Health and Nutrition Examination Survey, 1976 to 1980 (NHANES II). Ann Allergy. 1991;67(2 Pt 1):147-154.

37. Woolcock AJ, Peat JK, Salome CM, et al. Prevalence of bronchial hyperresponsiveness and asthma in a rural adult population. Thorax. 1987;42(5):361-368.

38. Kiley J, Smith R, Noel P. Asthma phenotypes. Curr Opin Pulm Med. 2007;13(1):19-23.

39. Wenzel SE. Asthma: defining of the persistent adult phenotypes. Lancet 2006;368(9537):804-813.

40. Cockcroft DW, Murdock KY, Berscheid BA, Gore BP. Sensitivity and specificity of histamine PC20 determination in a random selection of young college students. J Allergy Clin Immunol. 1992;89(1 Pt 1): 23-30.

41. Postma DS, Koppelman GH, Meyers DA. The genetics of atopy and airway hyperresponsiveness. Am J Respir Crit Care Med. 2000; 162(3 Pt 2):S118-S123.

42. Male D, Brostoff J, Roth D, Roitt I. Immunology. 7th ed. London: Mosby; 2006.

43. Beasley R, Pekkanen J, Pearce N. Has the role of atopy in the development of asthma been over-emphasized? Pediatr Pulmonol Suppl. 2001;23:149-150

44. Kay AB. The role of eosinophils in the pathogenesis of asthma. Trends Mol Med. 2005;11(4):148-152.

45. Constant SL, Brogdon JL, Piggott DA, et al. Resident lung antigenpresenting cells have the capacity to promote Th2 T cell differentiation in situ. J Clin Invest. 2002;110(10):1441-1448.

46. Julia V, Hessel EM, Malherbe L, Glaichenhaus N, O`Garra A, Coffman RL. A restricted subset of dendritic cells captures airborne antigens and remains able to activate specific $\mathrm{T}$ cells long after antigen exposure. Immunity. 2002;16(2):271-283.

47. Riese RJ, Chapman HA. Cathepsins and compartmentalization in antigen presentation. Curr Opin Immunol. 2000;12(1): 107-113.
48. Kuipers H, Heirman C, Hijdra D, et al. Dendritic cells retrovirally overexpressing IL-12 induce strong Th1 responses to inhaled antigen in the lung but fail to revert established Th2 sensitization. J Leukoc Biol. 2004;76(5):1028-1038.

49. Anderson GP. The immunobiology of early asthma. Med J Aust. 2002; 177 Suppl:S47-S49.

50. Dahlen B, Shute J, Howarth P. Immunohistochemical localisation of the matrix metalloproteinases MMP-3 and MMP-9 within the airways in asthma. Thorax. 1999;54(7):590-596.

51. Kaur D, Saunders R, Berger P, et al. Airway smooth muscle and mast cell-derived CC chemokine ligand 19 mediate airway smooth muscle migration in asthma. Am J Respir Crit Care Med. 2006;174(11): $1179-1188$

52. Bradding P, Walls AF, Holgate ST. The role of the mast cell in the pathophysiology of asthma. J Allergy Clin Immunol. 2006;117(6): 1277-1284.

53. Wenzel SE, Balzar S, Cundall M, Chu HW. Subepithelial basement membrane immunoreactivity for matrix metalloproteinase 9: association with asthma severity, neutrophilic inflammation, and wound repair. J Allergy Clin Immunol. 2003;111(6):1345-1352.

54. Holsapple MP, Jones D, Kawabata TT, et al. Assessing the potential to induce respiratory hypersensitivity. Toxicol Sci. 2006; 91(1):4-13.

55. Ogawa Y, Calhoun WJ. The role of leukotrienes in airway inflammation J Allergy Clin Immunol. 2006;118(4):789-798; quiz 799-800.

56. Bradding P, Holgate ST. Immunopathology and human mast cell cytokines. Crit Rev Oncol Hematol. 1999;31(2):119-133.

57. Nouri-Aria KT, Irani AM, Jacobson MR, et al. Basophil recruitment and IL-4 production during human allergen-induced late asthma. J Allergy Clin Immunol. 2001;108(2):205-211.

58. Nissim Ben Efraim AH, Levi-Schaffer F. Tissue remodeling and angiogenesis in asthma: the role of the eosinophil. Ther Adv Respir Dis. 2008;2(3):163-171.

59. Lampinen M, Carlson M, Hakansson LD, Venge P. Cytokine-regulated accumulation of eosinophils in inflammatory disease. Allergy. 2004;59(8):793-805.

60. Lee JJ, Dimina D, Macias MP, et al. Defining a link with asthma in mice congenitally deficient in eosinophils. Science. 2004;305(5691): 1773-1776.

61. Schmid-Grendelmeier P, Altznauer F, Fischer B, et al. Eosinophils express functional IL-13 in eosinophilic inflammatory diseases. J Immunol. 2002;169(2):1021-1027.

62. Adelroth E, Morris MM, Hargreave FE, O’Byrne PM. Airway responsiveness to leukotrienes $\mathrm{C} 4$ and D4 and to methacholine in patients with asthma and normal controls. N Engl J Med. 1986;315(8):480-484.

63. Lee E, Robertson T, Smith J, Kilfeather S. Leukotriene receptor antagonists and synthesis inhibitors reverse survival in eosinophils of asthmatic individuals. Am J Respir Crit Care Med. 2000;161(6): 1881-1886.

64. Marom Z, Shelhamer JH, Bach MK, Morton DR, Kaliner M. Slow-reacting substances, leukotrienes C4 and D4, increase the release of mucus from human airways in vitro. Am Rev Respir Dis. 1982; 126(3):449-451.

65. Frigas E, Motojima S, Gleich GJ. The eosinophilic injury to the mucosa of the airways in the pathogenesis of bronchial asthma. Eur Respir $J$ Suppl. 1991;13:123s-135s.

66. Jacobsen EA, Taranova AG, Lee NA, Lee JJ. Eosinophils: singularly destructive effector cells or purveyors of immunoregulation? J Allergy Clin Immunol. 2007;119(6):1313-1320.

67. Van Hove CL, Maes T, Joos GF, Tournoy KG. Chronic inflammation in asthma: a contest of persistence vs resolution. Allergy. 2008;63(9):1095-1109.

68. Brightling CE, Bradding P, Symon FA, Holgate ST, Wardlaw AJ, Pavord ID. Mast-cell infiltration of airway smooth muscle in asthma. $N$ Engl J Med. 2002;346(22):1699-1705.

69. Plante S, Semlali A, Joubert P, et al. Mast cells regulate procollagen I (alpha 1) production by bronchial fibroblasts derived from subjects with asthma through IL-4/IL-4 delta 2 ratio. J Allergy Clin Immunol. 2006;117(6):1321-1327. 
70. Lipscomb MF, Masten BJ. Dendritic cells: immune regulators in health and disease. Physiol Rev. 2002;82(1):97-130.

71. Wills-Karp M, Luyimbazi J, Xu X, et al. Interleukin-13: central mediator of allergic asthma. Science. 1998;282(5397):2258-2261.

72. Cho JY, Miller M, Baek KJ, et al. Inhibition of airway remodeling in IL-5-deficient mice. J Clin Invest. 2004;113(4):551-560.

73. Humbles AA, Lloyd CM, McMillan SJ, et al. A critical role for eosinophils in allergic airways remodeling. Science. 2004;305(5691):1776-1779.

74. Munitz A, Bachelet I, Levi-Schaffer F. Reversal of airway inflammation and remodeling in asthma by a bispecific antibody fragment linking CCR3 to CD300a. J Allergy Clin Immunol. 2006;118(5):1082-1089.

75. Ordonez CL, Khashayar R, Wong HH, et al. Mild and moderate asthma is associated with airway goblet cell hyperplasia and abnormalities in mucin gene expression. Am J Respir Crit Care Med. 2001;163(2): 517-523.

76. Perez-Vilar J. Mucin granule intraluminal organization. Am J Respir Cell Mol Biol. 2007;36(2):183-190.

77. Bergeron C, Boulet LP. Structural changes in airway diseases: characteristics, mechanisms, consequences, and pharmacologic modulation. Chest. 2006;129(4):1068-1087.

78. Smit JJ, Lukacs NW. A closer look at chemokines and their role in asthmatic responses. Eur J Pharmacol. 2006;533(1-3):277-288.

79. Johnson SR, Knox AJ. Synthetic functions of airway smooth muscle in asthma. Trends Pharmacol Sci. 1997;18(8):288-292.

80. Panettieri RA Jr. Airway smooth muscle: an immunomodulatory cell. J Allergy Clin Immunol. 2002;110 Suppl 6:S269-S274.

81. Bosse Y, Pare PD, Seow CY. Airway wall remodeling in asthma: from the epithelial layer to the adventitia. Curr Allergy Asthma Rep. 2008; 8(4):357-366.

82. Dube J, Chakir J, Laviolette M, et al. In vitro procollagen synthesis and proliferative phenotype of bronchial fibroblasts from normal and asthmatic subjects. Lab Invest. 1998;78(3):297-307.

83. Carlsen KH, Kowalski ML. Asthma, allergy, the athlete and the Olympics. Allergy. 2008;63(4):383-386.

84. Humbert M, Menz G, Ying S, et al. The immunopathology of extrinsic (atopic) and intrinsic (non-atopic) asthma: more similarities than differences. Immunol Today. 1999;20(11):528-533.

85. Corrigan C. Mechanisms of intrinsic asthma. Curr Opin Allergy Clin Immunol. 2004;4(1):53-56.

86. Jayaratnam A, Corrigan CJ, Lee TH. The continuing enigma of non-atopic asthma. Clin Exp Allergy. 2005;35(7):835-837.

87. Humbert M, Grant JA, Taborda-Barata L, et al. High-affinity IgE receptor (FcepsilonRI)-bearing cells in bronchial biopsies from atopic and nonatopic asthma. Am J Respir Crit Care Med. 1996;153(6 Pt 1): 1931-1937.

88. Ying S, Humbert M, Meng Q, et al. Local expression of epsilon germline gene transcripts and RNA for the epsilon heavy chain of IgE in the bronchial mucosa in atopic and nonatopic asthma. J Allergy Clin Immunol. 2001;107(4):686-692.

89. Ying S, Meng Q, Zeibecoglou K, et al. Eosinophil chemotactic chemokines (eotaxin, eotaxin-2, RANTES, monocyte chemoattractant protein-3 (MCP-3), and MCP-4), and C-C chemokine receptor 3 expression in bronchial biopsies from atopic and nonatopic (Intrinsic) asthmatics. $J$ Immunol. 1999;163(11):6321-6329.

90. Humbert M, Durham SR, Ying S, et al. IL-4 and IL-5 mRNA and protein in bronchial biopsies from patients with atopic and nonatopic asthma: evidence against "intrinsic" asthma being a distinct immunopathologic entity. Am J Respir Crit Care Med. 1996;154(5): 1497-1504.

91. Ying S, Humbert M, Barkans J, et al. Expression of IL-4 and IL-5 mRNA and protein product by $\mathrm{CD} 4^{+}$and $\mathrm{CD} 8^{+} \mathrm{T}$ cells, eosinophils, and mast cells in bronchial biopsies obtained from atopic and nonatopic (intrinsic) asthmatics. J Immunol. 1997;158(7):3539-3544.

92. Szczeklik A, Sanak M. The broken balance in aspirin hypersensitivity. Eur J Pharmacol. 2006;533(1-3):145-155.

93. Kim SH, Park HS. Pathogenesis of nonsteroidal antiinflammatory druginduced asthma. Curr Opin Allergy Clin Immunol. 2006;6(1):17-22.

94. Ito K, Chung KF, Adcock IM. Update on glucocorticoid action and resistance. J Allergy Clin Immunol. 2006;117(3):522-543.
95. Dykewicz MS. Occupational asthma: current concepts in pathogenesis, diagnosis, and management. J Allergy Clin Immunol. 2009;123(3):519-528; quiz 529-530.

96. Balmes J, Becklake M, Blanc P, et al. American Thoracic Society Statement: occupational contribution to the burden of airway disease. Am J Respir Crit Care Med. 2003;167(5):787-797.

97. Tarlo SM, Balmes J, Balkissoon R, et al. Diagnosis and management of work-related asthma: American College Of Chest Physicians Consensus Statement. Chest. 2008;134 Suppl 3:1S-41S.

98. Lecomte J. Asthma and exercise. Rev Med Brux. 2002;23(4): A206-A210.

99. Parsons JP, Kaeding C, Phillips G, Jarjoura D, Wadley G, Mastronarde JG. Prevalence of exercise-induced bronchospasm in a cohort of varsity college athletes. Med Sci Sports Exerc. 2007;39(9): 1487-1492.

100. Weiler JM, Bonini S, Coifman R, et al. American Academy of Allergy, Asthma and Immunology Work Group report: exercise-induced asthma. J Allergy Clin Immunol. 2007;119(6):1349-1358.

101. Anderson SD, Daviskas E. The mechanism of exercise-induced asthma is ... J Allergy Clin Immunol. 2000;106(3):453-459.

102. Anderson SD. Is there a unifying hypothesis for exercise-induced asthma? J Allergy Clin Immunol. 1984;73(5 Pt 2):660-665.

103. McFadden ER Jr. Hypothesis: exercise-induced asthma as a vascular phenomenon. Lancet. 1990;335(8694):880-883.

104. Buist AS. Definitions. In: Barnes PJ, Drazen JM, Rennard SI, Thomson NC, editors. Asthma and COPD. 2nd ed. San Diego, CA: Academic Press, Elsevier; 2009:3-7.

105. Kraft M, Martin RJ, Wilson S, Djukanovic R, Holgate ST. Lymphocyte and eosinophil influx into alveolar tissue in nocturnal asthma. Am J Respir Crit Care Med. 1999;159(1):228-234.

106. Hamzaoui A, Chaouch N, Grairi H, Ammar J, Hamzaoui K. Inflammatory process of $\mathrm{CD} 8^{+} \mathrm{CD} 28^{-} \mathrm{T}$ cells in induced sputum from asthmatic patients. Mediators Inflamm. 2005;2005(3):160-166.

107. O'Sullivan SM. Asthma death, $\mathrm{CD} 8^{+} \mathrm{T}$ cells, and viruses. Proc Am Thorac Soc. 2005;2(2):162-165.

108. Truyen E, Coteur L, Dilissen E, et al. Evaluation of airway inflammation by quantitative Th1/Th 2 cytokine mRNA measurement in sputum of asthma patients. Thorax. 2006;61(3):202-208.

109. Gordon S. Alternative activation of macrophages. Nat Rev Immunol. 2003;3(1):23-35.

110. Holt PG, Oliver J, Bilyk N, et al. Downregulation of the antigen presenting cell function(s) of pulmonary dendritic cells in vivo by resident alveolar macrophages. J Exp Med. 1993; 177(2):397-407.

111. MacLean JA, Xia W, Pinto CE, Zhao L, Liu HW, Kradin RL. Sequestration of inhaled particulate antigens by lung phagocytes. A mechanism for the effective inhibition of pulmonary cell-mediated immunity. Am J Pathol. 1996;148(2):657-666.

112. Bissonnette E. Alveolar macrophages in the pathogenesis of asthma. Recent Res Devol Allergy Clin Immunol. 2000;1:129-141.

113. Peters-Golden M. The alveolar macrophage: the forgotten cell in asthma. Am J Respir Cell Mol Biol. 2004;31(1):3-7.

114. Cooke RA, van der Veer AJ. Human sensitization. J Immunol. 1916;1: 201-305.

115. Drinkwater H. Mendelian hereditary in asthma. Br Med J. 1909;1:88.

116. Los H, Postmus PE, Boomsma DI. Asthma genetics and intermediate phenotypes: a review from twin studies. Twin Res. 2001;4(2): 81-93.

117. Rackemann FM. Studies in asthma. II. An analysis of two hundred and thirteen cases in which the patients were relieved for more than two years. Arch Intern Med. 1928;41:346-369.

118. Schwartz M. Heredity in bronchial asthma; a clinical and genetic study of 191 asthma probands and 50 probands with Baker's asthma. Acta Allergol Suppl (Copenh). 1952;2:1-288.

119. Spain WC, Cooke RA. Studies in specific hypersensitiveness. XI. The familial occurrence of hayfever and bronchial asthma. J Immunol. $1924 ; 9: 521-569$. 
120. Miller RL, Ho SM. Environmental epigenetics and asthma: current concepts and call for studies. Am J Respir Crit Care Med. 2008; 177(6): $567-573$.

121. Vercelli D. Discovering susceptibility genes for asthma and allergy. Nat Rev Immunol. 2008;8(3):169-182.

122. Barnes PJ. New drugs for asthma. Nat Rev Drug Discov. 2004;3(10): 831-844.

123. Kazani S, Wechsler ME, Israel E. The role of pharmacogenomics in improving the management of asthma. J Allergy Clin Immunol 125(2):295-302; quiz 303-304.

124. Koppelman GH, te Meerman GJ, Postma DS. Genetic testing for asthma. Eur Respir J. 2008;32(3):775-782.

125. Moffatt MF. Genes in asthma: new genes and new ways. Curr Opin Allergy Clin Immunol. 2008;8(5):411-417.

126. Madore AM, Perron S, Turmel V, Laviolette M, Bissonnette EY, Laprise C. Alveolar macrophages in allergic asthma: an expression signature characterized by heat shock protein pathways. Hum Immunol. 2010;71(2):144-150.

127. Zhu M, Zhao S. Candidate gene identification approach: progress and challenges. Int J Biol Sci. 2007;3(7):420-427.

128. Izuhara K, Saito H. Microarray-based identification of novel biomarkers in asthma. Allergol Int. 2006;55(4):361-367.

129. Laprise C, Sladek R, Ponton A, Bernier MC, Hudson TJ, Laviolette M. Functional classes of bronchial mucosa genes that are differentially expressed in asthma. BMC Genomics. 2004;5(1):21.

130. Willis-Owen SA, Cookson WO, Moffatt MF. Genome-wide association studies in the genetics of asthma. Curr Allergy Asthma Rep. 2009;9(1):3-9.

131. Griffiths AJF, Gelbart WM, Miller JH, Lewontin RC. Les applications de la technologie de l'ADN recombinant. In: De Boeck Université editors. Analyse génétique moderne. Paris; 2001:341-412.

132. Bennett P. Demystified ... microsatellites. Mol Pathol. 2000;53(4) 177-183.

133. Laird NM, Lange C. Family-based methods for linkage and association analysis. Adv Genet. 2008;60:219-252.

134. Rice JP, Saccone NL, Corbett J. Model-based methods for linkage analysis. Adv Genet. 2008;60:155-173.

135. Risch N, Merikangas K. The future of genetic studies of complex human diseases. Science. 1996;273(5281):1516-1517.

136. International HapMap Consortium. A haplotype map of the human genome. Nature. 2005;437(7063):1299-1320.

137. Mocellin S, Rossi CR. Principles of gene microarray data analysis. Adv Exp Med Biol. 2007;593:19-30.

138. Denham S, Koppelman GH, Blakey J, et al. Meta-analysis of genome-wide linkage studies of asthma and related traits. Respir Res. 2008; 9:38.

139. Rolph MS, Sisavanh M, Liu SM, Mackay CR. Clues to asthma pathogenesis from microarray expression studies. Pharmacol Ther. 2006;109(1-2):284-294.

140. Moffatt MF, Kabesch M, Liang L, et al. Genetic variants regulating ORMDL3 expression contribute to the risk of childhood asthma. Nature. 2007;448(7152):470-473.

141. Verlaan DJ, Berlivet S, Hunninghake GM, et al. Allele-specific chromatin remodeling in the ZPBP2/GSDMB/ORMDL3 locus associated with the risk of asthma and autoimmune disease. Am J Hum Genet 2009;85(3):377-393.
142. Rice TK, Schork NJ, Rao DC. Methods for handling multiple testing. Adv Genet. 2008;60:293-308.

143. Ziegler A, Konig IR, Thompson JR. Biostatistical aspects of genomewide association studies. Biom J. 2008;50(1):8-28.

144. Ioannidis JP, Trikalinos TA, Khoury MJ. Implications of small effect sizes of individual genetic variants on the design and interpretation of genetic association studies of complex diseases. Am J Epidemiol. 2006;164(7):609-614.

145. Reimers M. Statistical analysis of microarray data. Addict Biol. 2005; 10(1):23-35.

146. Chanock SJ,ManolioT, Boehnke M, etal. Replicating genotype-phenotype associations. Nature. 2007;447(7145):655-660.

147. Guerra S, Martinez FD. Asthma genetics: from linear to multifactorial approaches. Annu Rev Med. 2008;59:327-341.

148. Martinez FD. Gene-environment interactions in asthma: with apologies to William of Ockham. Proc Am Thorac Soc. 2007;4(1):26-31.

149. Valdar W, Solberg LC, Gauguier D, et al. Genetic and environmental effects on complex traits in mice. Genetics. 2006;174(2): 959-984

150. Eder W, Klimecki W, Yu L, et al. Opposite effects of CD 14/-260 on serum IgE levels in children raised in different environments. JAllergy Clin Immunol. 2005;116(3):601-607.

151. Simpson A, John SL, Jury F, et al. Endotoxin exposure, CD14, and allergic disease: an interaction between genes and the environment. Am J Respir Crit Care Med. 2006;174(4):386-392.

152. Zambelli-Weiner A, Ehrlich E, Stockton ML, et al. Evaluation of the CD14/-260 polymorphism and house dust endotoxin exposure in the Barbados Asthma Genetics Study. J Allergy Clin Immunol. 2005; 115(6):1203-1209.

153. Cameron L, Webster RB, Strempel JM, et al. Th2 cell-selective enhancement of human IL13 transcription by IL13-1112C $>$ T, a polymorphism associated with allergic inflammation. J Immunol. 2006;177(12):8633-8642.

154. Krebs JE. Moving marks: dynamic histone modifications in yeast. Mol Biosyst. 2007;3(9):590-597.

155. Nightingale KP, O’Neill LP, Turner BM. Histone modifications: signalling receptors and potential elements of a heritable epigenetic code. Curr Opin Genet Dev. 2006;16(2):125-136.

156. Waterland RA, Jirtle RL. Transposable elements: targets for early nutritional effects on epigenetic gene regulation. Mol Cell Biol. 2003;23(15):5293-5300.

157. Alati R, Al Mamun A, O’Callaghan M, Najman JM, Williams GM. In utero and postnatal maternal smoking and asthma in adolescence. Epidemiology. 2006;17(2):138-144.

158. Li YF, Langholz B, Salam MT, Gilliland FD. Maternal and grandmaternal smoking patterns are associated with early childhood asthma. Chest. 2005;127(4):1232-1241.

159. Magnusson LL, Olesen AB, Wennborg H, Olsen J. Wheezing, asthma, hayfever, and atopic eczema in childhood following exposure to tobacco smoke in fetal life. Clin Exp Allergy. 2005;35(12): 1550-1556.

160. Kabesch M, Schedel M, Carr D, et al. IL-4/IL-13 pathway genetics strongly influence serum IgE levels and childhood asthma. J Allergy Clin Immunol. 2006;117(2):269-274.

Journal of Asthma and Allergy

\section{Publish your work in this journal}

The Journal of Asthma and Allergy is an international, peer-reviewed open-access journal publishing original research, reports, editorials and commentaries on the following topics: Asthma; Pulmonary physiology; Asthma related clinical health; Clinical immunology and the immunological basis of disease; Pharmacological interventions and

new therapies. Issues of patient safety and quality of care will also be considered. The manuscript management system is completely online and includes a very quick and fair peer-review system, which is all easy to use. Visit http://www.dovepress.com/testimonials.php to read real quotes from published authors. 